\title{
CHILLING AND HEAT UNIT LEVELS AFFECT FOLIAR BUDBREAK OF SELECTED RED AND FREEMAN MAPLE CULTIVARS
}

\author{
by Barrett C. Wilson', Jeff L. Sibley², James E. Altland ${ }^{3}$, Eric H. Simonne ${ }^{4}$, and \\ D. Joseph Eakes ${ }^{5}$
}

\begin{abstract}
The effects of six levels of chilling (temp $<7^{\circ} \mathrm{C}$ ) on foliar budbreak of red maple (Acer rubrum) cultivars October Glory $^{\circledR}$ and 'Franksred' (Red Sunset $\left.{ }^{\circledR}\right)$ and Freeman maple $(A$. $\times$ freemanii) cultivar 'Autumn Fantasy' were evaluated in a study conducted from December 14, 1999, to April 7, 2000. October Glory had a greater minimum chilling hour requirement to initiate budbreak than 'Autumn Fantasy' and 'Franksred' (Red Sunset). However, once optimal chilling had been satisfied (near 600 hours), October Glory required fewer heat units than the other cultivars to reach $20 \%$ and $25 \%$ budbreak. For example, estimates for heat units required to reach $25 \%$ budbreak for October Glory were less than half that required for 'Autumn Fantasy' and 'Franksred' following 1,200 hours of chilling. Chilling was a determining factor in foliar budbreak for all cultivars, and with all three cultivars, increasing chilling produced greater budbreak percentages and the rate at which budbreak was initiated. All cultivars required fewer heat units for budbreak as chilling increased. All cultivars required over 1,700 heat units to initiate budbreak after 200 hours of chilling, but only 780 to 970 heat units after 600 hours and between 200 and 400 following 1,000 hours of chilling. Information from this and future studies may be used to facilitate the development of models for regional planting recommendations based on the amount chilling received in a given location. Calculated $\mathrm{r}^{2}$ values indicated the models provided a good fit to the data for all cultivars.
\end{abstract}

Key Words. Dormancy; endodormancy; budbreak; chilling; cold storage; heat requirement; provenance; Acer rubrum; Acer $\times$ freemanii.

Red maple (Acer rubrum) is a popular ornamental tree found naturally in the forests of eastern North America, from southern Canada to south Florida (Sternberg and Wilson 1995). The availability of over 58 red and Freeman maple (Acer $\times$ freemanii, a hybrid between red maple and silver maple, A. saccharinum) cultivars (Dirr 1998) demonstrates the enormous genetic variation, adaptability to nursery culture, and performance in the landscape for this group, along with its resulting popularity. The natural range of red maples is widespread, and research suggests that performance of red maple cultivars can vary greatly depending on their area of origin. Studies have demonstrated differences in regional adaptability based on fall color, color duration, time of peak fall color, stem diameter, height, and canopy width (Townsend et al. 1982; Sibley et al. 1995; Witte et al. 1996) for selections originating throughout the native range. The genetic basis for this diversity (Townsend 1977) makes red maple a good candidate for regional selection.

Endodormancy release, as controlled by chilling temperatures, is a major factor in determining a plant's performance in a given climate or hardiness zone. Dormancy in plants has been described as a state in which visible growth is temporarily suspended (Samish 1954; Romberger 1963; Amen 1968). In temperate-zone plants, periods of low temperature are necessary for dormancy transition (Crocker 1948; Saure 1985; Seeley 1994). Studies have shown that races of red maple from different provenances can vary in the chilling requirement necessary to complete rest (Perry and Wu 1960; Perry and Hellmers 1973; Townsend 1977). In the studies by Perry and Hellmers (1973) and Perry and Wu (1960), red maples originating from within the northern part of the natural range required a longer duration of chilling temperatures to break endodormancy than trees from the southern part. Dormancy release is of particular interest to the nursery industry, for early budbreak can lead not only to a longer growing season and accelerated production but can result in cold and frost damage (Townsend 1977; Lechowicz 1984).

While previous studies have established the chilling requirement for many deciduous fruit tree cultivars, leading to models for regional planting recommendations (Westwood 1993; Childers et al. 1995), no reports have documented the chilling requirements for individual red maple cultivars. The objectives of this study were to 1) establish whether chilling is a determining factor in red maple budbreak; and (2) evaluate cultivar 
responses to chilling. From this and future research, chilling requirements for individual red maple cultivars may be estimated, leading to models for regional planting recommendations similar to those used for tree fruit cultivars. Nursery growers and other professionals can use this information for more efficient crop and landscape management.

\section{MATERIALS AND METHODS}

Red maple cultivars October Glory ${ }^{\circledR}$ and 'Franksred' $\left(\right.$ Red Sunset $\left.^{\circledR}\right)$ and Freeman maple cultivar 'Autumn Fantasy' from tissue culture origin were obtained as $1.5-\mathrm{m}$ (5-ft) tall bare-root whips from A. McGill \& Son Nursery, Canby, Oregon, U.S., in February 1999. Trees were potted into 22-L (7-gal) containers using a 6:1 pinebark:sand substrate amended with $3 \mathrm{~kg} / \mathrm{m}^{3}(5 \mathrm{lb} /$ $\left.\mathrm{yd}^{3}\right)$ dolomitic limestone, $0.9 \mathrm{~kg} / \mathrm{m}^{3} \quad\left(1.5 \mathrm{lb} / \mathrm{yd}^{3}\right)$ $\operatorname{Micromax}^{\circledR}$ (O.M. Scotts Co., Marysville, $\mathrm{OH}$ ), and $6.3 \mathrm{~kg} / \mathrm{m}^{3}\left(11.1 \mathrm{lb} / \mathrm{yd}^{3}\right)$ 18-6-12 Osmocote ${ }^{\circledR}$ (O.M. Scotts Co.). Trees were grown outdoors with overhead irrigation using standard nursery practices at the Paterson Greenhouse Complex, Auburn, Alabama $\left(32^{\circ}\right.$ $36^{\prime} \mathrm{N} \times 85^{\circ} 29^{\prime} \mathrm{W}$, USDA Hardiness Zone 8a).

This study included six levels of chilling applied in increments of 200 hours (200 to 1,200), with each treatment consisting of three single-tree replications per cultivar. Chilling hours were calculated using the Old 45 Chilling Model (Powell et al. 1999). In this model, beginning October 1 , one hour at temperatures below $7^{\circ} \mathrm{C}\left(45^{\circ} \mathrm{F}\right)$ equals one chilling hour. On accumulation of 200 hours of natural, ambient chilling on December 14,1999, the first treatment was placed in a standard glass greenhouse maintained at a minimum temperature of $22^{\circ} \mathrm{C}\left(72^{\circ} \mathrm{F}\right)$ under natural photoperiods. Trees were positioned in a completely randomized design (CRD). Subsequent treatments were placed in the greenhouse after intervals of 200 chilling hours were accumulated. Treatments 1 through 4 (200 to 800 hours) accumulated chilling under natural conditions. Treatments 5 and $6(1,000$ to 1,200$)$ accumulated 925 hours of natural chilling; the remainder supplied while they were stored at $3^{\circ} \mathrm{C}\left(38^{\circ} \mathrm{F}\right)$ in a thermostatically controlled cooling unit (Funchess Hall, Auburn University, AL). Trees were weeded and watered by hand as needed.

After placement in the greenhouse, trees were monitored twice weekly for foliar budbreak until termination of the experiment on April 7, 2000. The total number of buds were counted for the terminal $30 \mathrm{~cm}$
(12 in.) of all branches. Budbreak was considered to be the point where overlapping bud scales began to separate enough to reveal leaves. The highest percentage of budbreak was recorded for each cultivar by April 7, 2000, and was used as the highest percentage attainable. Predicted heat unit values required to reach a percentage of budbreak for different chilling treatments, where one heat unit equals one hour in the greenhouse at a minimum base temperature of $22^{\circ} \mathrm{C}\left(72^{\circ} \mathrm{F}\right)$, were determined using regression analysis, using the SAS stepwise procedure to determine the best model for each cultivar (SAS 1996).

\section{RESULTS AND DISCUSSION}

In all cultivars, increasing the level of chilling accelerated the rate of foliar budbreak. Differences in the number of heat units required to reach budbreak at every chilling level were determined for each cultivar (Table 1). The level of chilling exposure required for foliar budbreak was inversely related to heat unit accumulation. By extending the chilling duration, fewer heat units were required to produce budbreak in the terminal $30 \mathrm{~cm}$ (12 in.) of each cultivar. The higher chilling treatments also generally exhibited the highest mean percentage budbreak over the course of the experiment. October Glory had a greater minimum chilling hour requirement to initiate budbreak than 'Autumn Fantasy' and 'Franksred' (Red Sunset). However, once optimal chilling had been satisfied (near 600 hours) October Glory required fewer heat units than the other cultivars to reach $20 \%$ and $25 \%$ budbreak. For example, estimates for heat units required to reach 25\% budbreak for October Glory were less than half that required for 'Autumn Fantasy' and 'Franksred' following 1,200 hours of chilling. Chilling was a determining factor in foliar budbreak for all cultivars, and with all three cultivars, increasing chilling produced greater budbreak percentages and the rate at which budbreak was initiated.

All cultivars required fewer heat units for budbreak as chilling increased. All cultivars required over 1,700 heat units to initiate budbreak after 200 hours of chilling, but only 780 to 970 heat units after 600 hours and between 200 and 400 following 1,000 hours of chilling. Calculated $r^{2}$ values indicate the models provided a good fit to the data for all cultivars.

These observations were similar to those recorded by Ashby et al. (1991) and Couvillon and Erez (1985). It may be concluded that growers who modify lifting 
Table 1. Predicted number of heat units required to reach a given budbreak percentage on the terminal $30 \mathrm{~cm}(12 \mathrm{in}$.) of stems of selected red maple cultivars, 1999-2000.

\begin{tabular}{|c|c|c|c|c|}
\hline Cultivar & Hours chilled & $\begin{array}{l}\text { Initial } \\
\text { budbreak }\end{array}$ & $\begin{array}{l}10 \% \\
\text { budbreak }\end{array}$ & $\begin{array}{l}25 \% \\
\text { budbreak }\end{array}$ \\
\hline & & \multicolumn{3}{|c|}{ Predicted number of heat units } \\
\hline \multirow[t]{7}{*}{ 'Autumn Fantasy' } & 200 & $1,716^{\mathrm{y}}$ & 2,085 & 2,487 \\
\hline & 400 & 1,245 & 1,615 & 2,017 \\
\hline & 600 & 843 & 1,212 & 1,614 \\
\hline & 800 & 509 & 878 & 1,280 \\
\hline & 1,000 & 243 & 612 & 1,015 \\
\hline & 1,200 & 46 & 415 & 817 \\
\hline & & \multicolumn{3}{|c|}{$\mathrm{r}^{2}=0.63$} \\
\hline \multirow[t]{7}{*}{ October Glory ${ }^{\circledR}$} & 200 & 1784 & 1850 & 1948 \\
\hline & 400 & 1,348 & 1,414 & 1,513 \\
\hline & 600 & 970 & 1,035 & 1,134 \\
\hline & 800 & 648 & 713 & 812 \\
\hline & 1,000 & 382 & 448 & 47 \\
\hline & 1,200 & 174 & 240 & 338 \\
\hline & & \multicolumn{3}{|c|}{$r^{2}=0.50$} \\
\hline \multirow[t]{7}{*}{ 'Franksred' (Red Sunset ${ }^{\circledR}$ ) } & 200 & 1,728 & 2,052 & 2,419 \\
\hline & 400 & 1,207 & 1,531 & 1,899 \\
\hline & 600 & 782 & 1,106 & 1,474 \\
\hline & 800 & 453 & 777 & 1,144 \\
\hline & 1,000 & 219 & 543 & 910 \\
\hline & 1,200 & 80 & 404 & 771 \\
\hline & & \multicolumn{3}{|c|}{$\mathrm{r}^{2}=0.66$} \\
\hline
\end{tabular}

${ }^{z}$ Calculated with PROC REG, using the SAS stepwise procedure to determine the best model.

y $\mathrm{One}$ heat unit equals one hour in greenhouse at a temperature of at least $22^{\circ} \mathrm{C}\left(72^{\circ} \mathrm{F}\right)$.

and transplanting schedules based on chilling accumulation could accelerate production of these cultivars. Tissue-cultured plantlets and rooted cuttings could be produced at a faster rate by alternating cold storage with greenhouse growing conditions (Wood and Hanover 1981; Sorenson et al. 1994). Also, the selections evaluated would be suitable landscape choices based on the amount of chilling received for much of the United States.

The interaction of chilling and subsequent heat necessary to release a plant from dormancy is a complex problem to understand. At first glance, an earlier study by Townsend (1977) appears to indicate that some southern red maple progenies have longer chilling requirements than more northern progenies. However, careful study indicates that the chilling levels received by all progenies prior to budbreak would have been the same. What varied was the subsequent heat units necessary to release the different progenies from dormancy. Our study provides good evidence of the importance of heat unit accumulation on budbreak of red maples following satisfactory chilling.
More research will be needed to develop regional planting models. The processes that lead to dormancy and budbreak within a plant consist of many interacting factors (temperature, light, physiological and chronological age of plant, apical dominance, provenance, hormonal balances, environmental conditions, drought, fertility, etc.). These factors as related to chilling and heat must be studied further to present a more accurate picture of specific chilling requirements in individual cultivars. Finally, one of the most critical concerns yet to be addressed is a determination of the optimal temperatures to break dormancy. The study presented here assumed ambient temperatures below $7^{\circ} \mathrm{C} \quad\left(45^{\circ} \mathrm{F}\right)$ and a constant $3^{\circ} \mathrm{C}\left(38^{\circ} \mathrm{F}\right)$ when applied in a cooler as adequate to accomplish chilling, and that maintaining the greenhouse environment above $22^{\circ} \mathrm{C}\left(72^{\circ} \mathrm{F}\right)$ was ideal for flushing. Perhaps lower or higher temperatures could be considered more effective for breaking dormancy. Also, differences between constant versus fluctuating temperatures in a natural or simulated environment merit additional study.

\section{LITERATURE CITED}

Amen, R.D.1968. A model of seed dormancy. Bot. Rev.34:1-31. Ashby, W.C., D.F. Bresnan, C.A. Huetteman, J.E. Preece, and P.L. Roth. 1991. Chilling and budbreak in silver maple. J. Environ. Hortic. 9:1-4.

Childers, N.F., J.R. Morris, and G.S. Sibbett. 1995. Modern Fruit Science: Orchard and Small Fruit Culture. Horticultural Pub., Gainesville, FL.

Couvillon, G.A., and A. Erez. 1985. Influence of prolonged exposure to chilling temperatures on budbreak and heat requirement for bloom of several fruit tree species. J. Am. Soc. Hortic. Sci. 110:47-50. 
Crocker, W. 1948. Growth of Plants. Reinhold Publishing, New York, NY.

Dirr, M.A. 1998. Manual of Woody Landscape Plants: Their Identification, Ornamental Characteristics, Culture, Propagation and Uses. Stipes Publishing, Champaign, IL.

Lechowicz, M.J. 1984. Why do temperate deciduous trees leaf out at different times? Adaptation and ecology of forest communities. Am. Nat. 124:821-842.

Perry, T.O., and H. Hellmers. 1973. Effects of abscisic acid on growth and dormancy of races of red maple. Bot. Gaz. 134:283-289.

Perry,T.O., and W.L.Wu. 1960. Genetic variation in the winter chilling requirement for date of dormancy break for Acer rubrum. Ecology 41:790-794.

Powell, A., D. Himelrick, W. Dozier, and D. Williams. 1999. Fruit culture in Alabama-Winter chilling requirements. Ala. Coop. Ext. Sys. Bull. ANR-53-D.

Romberger,J.A. 1963. Meristems, growth, and development in woody plants. USDA Forest Serv. Tech. Bull. 1293.

Samish, R.M. 1954. Dormancy in woody plants. Ann. Rev. Plant Physiol. 5:183-204.

SAS Institute Inc. 1996. SAS User's Guide. Version 6.12. SAS Institute, Inc., Cary, NC.

Saure, M.C. 1985. Dormancy release in deciduous fruit trees. Hortic. Rev. 7:239-300.

Seeley, S.D. 1994. Dormancy-The black box. HortScience 29:1248

Sibley, J.L., D.J. Eakes, C.H. Gilliam, G.J. Keever, and W.A. Dozier, Jr. 1995. Growth and fall color of red maple selections in the southeastern United States. J. Environ. Hortic. 13:51-53.

Sorenson, E., C.F. Williams, R.H. Walser, J.D. Davis, and P. Barker. 1984. Growth response of Acer grandidentatum Nutt. to chilling treatments. J. Environ. Hortic. 2:128-130.

Sternberg, G., and J. Wilson. 1995. Landscaping With Native Trees. Chapters Publishing, Shelburne,VT.

Townsend, A.M. 1977. Characteristics of red maple progenies from different geographic areas. J. Am. Soc. Hortic. Sci. 102:461-466.
Townsend, A.M., J.W. Wright, W.F. Beineke, R.P. Guries, and C.A. Mohn. 1982. Early patterns of flowering, winter injury, and flushing of red maple progenies grown in five locations. Can. J. For. Res. 12:814-821.

Westwood, M.N. 1993. Temperate Zone Pomology: Physiology and Culture. Timber Press, Portland, OR.

Witte, W.T., R. Sauve, M.T. Mmbaga, and P.C. Flanagan. 1996. Maple evaluations at TSU-NCRS. Proc. Southern Nursery Assoc. Res. Conf. 41:385-392.

Wood, B.W., and J.W. Hanover. 1981. Environmental control of sugar maple seedling growth. Research ReportMichigan State University Agric. Exp. Sta., Jan. 1981:1-10.

Acknowledgments. This project was funded in part by a grant from the J. Frank Schmidt Charitable Foundation, Boring, Oregon.

${ }^{1}$ Graduate Research Assistant

${ }^{2} *$ Associate Professor

${ }^{5}$ Professor

Department of Horticulture

101 Funchess Hall

Auburn University, AL 36849, U.S.

${ }^{3}$ Assistant Professor

North Willamette Research and Extension Center

Oregon State University

15210 NE Miley Road

Aurora, OR 97002-9543, U.S.

${ }^{4}$ Assistant Professor

Horticultural Sciences Department

1241 Fifield Hall

University of Florida

Gainesville, FL 32611-0690, U.S.

*Corresponding author: Jeff L. Sibley. 
Résumé. Les effets de six niveaux de froid (températures $<7^{\circ} \mathrm{C}$ ) sur l'ouverture des bourgeons foliaires d'érables rouges (Acer rubrum) October Glory ${ }^{\circledR}$ et 'Franksred' (Red Sunset ${ }^{\circledR}$ ) ainsi que d'érables de Freeman (A. $\times$ freemanii) 'Autumn Fantasy' ont été évalués au cours d'une étude menée entre le 14 décembre 1999 et le 7 avril 2000. October Glory avait une plus grande exigence en terme d'heures minimum de froid afin d'initier l'ouverture des bourgeons que 'Autumn Fantasy' et 'Franksred' (Red Sunset). Cependant, une fois le niveau optimal de froid atteint - près de 600 heures -, October Glory exigeait moins d'unités de chaleur que les autres cultivars pour atteindre 20 et $25 \%$ d'éclosion des bourgeons. Par exemple, les estimations en regard des unités de chaleur pour atteindre 25\% d'ouverture des bourgeons pour le October Glory étaient de moins de moitié de celles nécessaires pour le 'Autumn Fantasy' et le 'Franksred', et ce après 1200 heures de froid. Le froid était un facteur déterminant dans l'éclosion des bourgeons foliaires pour les tous les cultivars; pour les trois cultivars, un froid accrû résultait en des pourcentages plus forts d'ouverture de bourgeons. Tous les cultivars requéraient moins d'unités de chaleur pour l'éclosion des bourgeons à mesure que le froid augmentait. Tous les cultivars avaient besoin de plus de 1700 unités de chaleur pour initier l'éclosion des bourgeons après 200 heures de froid, mais seulement 780 à 970 unités de chaleur après 600 heures, et entre 200 et 400 unités après 1000 heures de froid. Les données de la présente étude, et d'autres à venir, pourraient être utilisées pour faciliter le développement de modèles pour des recommandations régionales de plantation basées sur la quantité de froid reçue dans une endroit donné. Les valeurs de $\mathrm{r}^{2}$ calculées ont indiqué que les modèles donnent une bonne description des données pour tous les cultivars.

Zusammenfassung. In einer Studie mit dem Durchführungszeitraum vom 14.12.99 - 07.04.2001 wurde der Einfluss von 6 Frostgraden auf den Aufbruch der Blattknospen bei Rotahorn-Kultivaren October Glory ${ }^{\circledR}$ und Franksred und Freeman-Ahorn-Kultivar Autumn Fantasy bewertet. October Glory hatte eine größere Mindestfrostdaueranforderung, um die Knospung zu verursachen als Franksred und Autumn Fantasy. Trotzdem die optimale Befrostungsdauer erst mal erfolgreich war (fast 600 Stunden) erforderte October Glory weniger Hitzeeinheiten als die anderen Kultivare, um $20 \%$ und $25 \%$ Knospung zu erzielen. Beispielsweise lagen die Schätzungen für die Hitzeanforderungen, um 25\% Knospung zu erreichen, bei October Glory halb so viel wie für Autumn Fantasy, gefolgt von Franksred mit ca. 1200 Stunden. Das Frosten war der limitierende Faktor bei allen Blattknospen und verstärktes Frosten bewirkte einen höheren Knospungsanteil und der Rate, wann das Knospenschieben initiiert wurde. Alle Kultivare erfordern weniger Hitze bei steigender Befrostung. Alle Kultivare erfordern über 1700 Wärmeeinheiten, um die Knospung nach 200 Stunden zu initiieren, aber nur 780-970 Wärmeeinheiten nach 600 Stunden Frost und 200-400 Wärmeeinheiten nach 1000 Stunden Frostbehandlung. Die Informationen aus dieser und zukünftigen Studien können verwendet werden, um Modele für regionale Pflanzempfehlungen $\mathrm{zu}$ entwickeln, die auf den erforderlichen Frostmengen für eine bestimmte Region basieren. Die kalkulierten $r^{2}$ Werte zeigten, dass die Modele eine gute Passgenauigkeit für die Daten bei allen Kultivaren liefern.

Resumen. En un estudio llevado a cabo de Diciembre 14 de 1999 a Abril 7 de 2000, para evaluar el efecto de seis niveles de horas frío (Temp. $<7^{\circ} \mathrm{C}$ ) sobre las yemas foliares en los cultivares de maple rojo (Acer rubrum) October Glory ${ }^{\circledR}$ y 'Franksred' (Red Sunset ${ }^{\circledR}$ ), y cultivares de maple Freeman (A. $\times$ freemanii) 'Autumn Fantasy', se encontró que October Glory tuvo mayor requerimiento de horas frío para iniciar el rompimiento de las yemas que 'Autumn Fantasy' and 'Franksred' (Red Sunset). Sin embargo, una vez satisfecho el número de horas óptimo (cerca de 600), October Glory requirió menos unidades de calor que los otros cultivares para alcanzar $20 \%$ y $25 \%$ de rompimiento. Por ejemplo, las estimaciones de las unidades de calor requeridas para alcanzar $25 \%$ de rompimiento de yemas para October Glory fueron menores que la mitad requerida para 'Autumn Fantasy' y 'Franksred' en las siguientes 1200 de enfriamiento. El enfriamiento fue el factor determinante en el rompimiento de la yema para todos los cultivares, y con todos los tres cultivares, el aumento del enfriamiento produjo mayores porcentajes y tasas a las cuales el rompimiento se inició. Todos los cultivares requirieron menores unidades de calor para el rompimiento a medida que el enfriamiento se inició. Todos los cultivares requirieron arriba de 1700 unidades de calor para iniciar el rompimiento después de 200 horas de enfriamiento, pero solamente 780-970 unidades de calor después de 600 horas y entre 200-400 en las siguientes 100 horas de enfriamiento. La información de este estudio puede ser usada para facilitar el desarrollo de modelos para recomendaciones de plantaciones regionales basadas en la cantidad de enfriamiento recibido en una localidad dada. Los valores de $r^{2}$ calculados indicaron que los modelos proporcionan un buen ajuste de los datos para todos los cultivares. 